Globalisation, reflexive modernisation, and development: the case of India

\author{
David Pick \\ and \\ Kandy Dayaram
}

Author affiliations:

David Pick

Lecturer in Management

Curtin University of Technology

Kandy Dayaram

Lecturer in Management

Curtin University of Technology

Corresponding author:

David Pick

Curtin Business School

Curtin University of Technology

GPO Box U1987

Perth

Western Australia 6845

Ph: + 61892662705

Fax: +61 892667897

e-mail: david.pick@cbs.curtin.edu.au 


\section{Author biographies:}

David Pick is a Lecturer in Management at Curtin Business School, Curtin University of Technology. His research interests focus on public policy and management paying particular attention to examining the influences and effects of reflexive modernisation and globalisation.

Kandy Dayaram has a Doctorate in Public Management and is a lecturer at Curtin University of Technology. Her research interests are in change, strategic policy analysis and international management. 


\title{
Globalisation, reflexive modernisation and development: the case of India
}

\author{
Abstract \\ Purpose: the purpose of this paper is to use the theoretical insights provided by reflexive \\ modernisation in examining the effects of globalisation on the development policies and \\ trajectories of India.
}

Approach: after a presentation of the main ideas and concepts of reflexive modernisation and globalisation, the principal characteristics of the reflexive modernisation of India are identified and discussed.

Findings: this paper demonstrates that the development path taken by India is characterised by ambiguity, contradiction, and paradox. There is much doubt, uncertainty, and debate in academic, political, and social forums about whether India is on the right development path as the nation attempts to graft western-style capitalist structures and technologies onto traditional ways of life. Indeed, in its drive towards economic development and enhanced social wellbeing India is at the same time compromising that development and well-being through the production of risks.

Limitations: there are two main limitations of this paper. The first relates to reflexive modernisation. It is a much discussed and controversial theory that requires further enhancement, particularly with regard to developing nations. The second relates specifically to India in that it is difficult to make generalisations about such a diverse nation.

Implications: in spite of its limitations, reflexive modernisation offers a sound theoretical foundation for alternative perspectives and policy approaches to development. As developing nations such as India engage with global economic, cultural, and political structures and institutions, they are at the same time transforming and being transformed by the influences that these structures and institutions exert. 
Key words: India, reflexive modernisation, globalisation, development, policy.

\section{Conceptual paper}




\section{Introduction}

Both reflexive modernisation and globalisation are much discussed and controversial topics. For example, analyses by Beck (1998), Clark (1998), and Dannreuther and Lekhi (2000) support the claim that globalisation is surrounded by imprecision and conceptual confusion and is deeply contested in many directions. In this paper, it is argued that globalisation is a multi-directional and multi-dimensional process in which communications technology, ecology, work organisation, culture, and civil society are all implicated in the transformation of sovereign nations by global actors with varying levels of power, orientations, identities, and networks (Beck, 2000). In adopting a transformationalist approach (Held, McGrew Goldblatt, and Perraton, 1999) it is necessary to adopt a broad account of globalisation and the reflexive modernisation thesis provides one such framework.

There has been much debate in the literature about reflexive modernisation. Elliott (2002) developed a detailed critique arguing that it over-emphasises the transformational power of risk, fails to reconcile reflexivity and reflection, and gives too much prominence to modernity. Furthermore, Beck, Bonss, and Lau (2003) point out that reflexive modernisation has a Western bias and there is doubt whether it is an appropriate framework for analysing developing or non-Western nations. However, in a time when we are confronted by increasingly complex and severe global economic, social, political, and environmental problems, novel insights and ideas are essential. Reflexive modernisation is particularly useful in this respect. It can help explore the connection between society, business, and government at the global, regional, national, and local contexts enabling these different levels of influence to be understood in their entirety. 
The argument that reflexive modernisation over-emphasises risk stems from Beck’s (1992) claim that regardless of social class everyone is equally united in a community of fate. However, as Elliott (2002) points out, emphasising risk as a major driving force carries with it the danger of ignoring the influence of asymmetrical power relationships of social class evidenced in the emerging gap between information-rich and information-poor communities and the socially excluded underclass. Social inequality and social division rather than being equalised by risk may in fact be accentuated.

Reflexive modernisation may also be criticised for assuming a modernist perspective. Elliott (2002) argues that in maintaining that society is going through a period of transition to a new modernity, reflexive modernisation theorists see this second modernity as a continuation of the first modernity. This then excludes the possibility that society may be undergoing a transformation beyond modernity or that there are other pathways to the second modernity. In addition, problems arise in the way reflexivity and reflection are treated as separate phenomena in reflexive modernisation theory. As Elliott (2002) points out, the problem here is that in splitting reflexivity and reflection into mutually exclusive categories, blind social processes and practices (reflex) are separated from knowledge residing with social actors (reflection). Rather than reflex and reflection being separate, they are bound together in a complex relationship requiring the development of more sophisticated analysis and explanations.

The debate about reflexive modernisation has also so far missed examining whether the theoretical perspectives provided are applicable to so-called ‘Third World' or 'developing' nations. The central premise of the reflexive modernisation thesis is the re-shaping of Western society after the end of the Cold War. Beck (1994) discusses the role of 'modernity' 
in the transformation of 'traditional' (Western European) society into ‘industrial' social forms and the subsequent 'reflexive modernisation' of that society. The omission of developing nations by reflexive modernisation theorists is important because it is becoming apparent that new social and economic structures are emerging that do not conform to the old conceptions of worldwide social and economic divisions (eg 'North/South', 'Developed/Less Developed', 'First World/Third World', traditional/modern). Held and McGrew (2002, p.81) argue that the emerging social architecture, 'divides humanity into elites, the bourgeoisie, the marginalised, and the impoverished, [cutting] across territorial and cultural boundaries, rearranging the world into the winners and losers of globalisation'. That which separates nations is the relative proportions of these groups residing in that particular territory. Indeed Giddens (1994) identifies this very phenomenon contending that globalisation has made the term 'developing societies' redundant. Because the processes of reflexive modernisation are global, it is necessary to investigate whether and how it can be more than a theory of an emerging new epoch in Western industrial nations.

Beck, et al. (2003), point out that the nations of Africa, Asia and South America have to a large extent never experienced the same modernisation of society than North America and Europe. However, it is significant that they are subject to the same contemporary, disruptive influences. This is important because globalisation cannot be simply looked upon as a synonymous with 'Westernisation'. India is a rapidly emerging global economic power with a population of 1.03 billion, growing at over 21 per cent per annum (Census of India, 2001) accounting for one in six of the world's population. Like other nations at a similar stage of development (eg China, Brazil, South Africa, Indonesia), India is creating its own version of reflexive modernity and engagement with globalisation. As these nations develop their economies, they are becoming more influential on the world stage and as their influence 
increases, the social, economic, and political situation in nations such as India will become important in world affairs. Attendance by 'Outreach Leaders' of developing nations including the Indian Prime Minister - at the 2005 G8 summit reflects this growing significance. It is therefore essential to understand the dynamics of the relationships between business, government, and society in various national contexts beyond those nations adopting a Western capitalist model. As Beck (1994) points out, the intensification of globalising influences has significant disruptive effects on these relationships, compromising national well-being. Thus, the development of more complete theory of reflexive modernisation and globalisation requires the analysis of nations plotting a non-Western path. In many respects, the issue with reflexive modernisation is a matter of focus rather than applicability.

This paper aims to demonstrate the usefulness of reflexive modernisation as a framework to investigate the effects of policy trajectories and to provide critical insights into the effects and implications of national development programs of developing nations using the example of India. In analysing the policy formulation and developmental tracks of India, it is clear that whilst Western-style capitalist forces and influences of globalisation, emphasising the creation of a global free market, deregulation, privatisation, structural adjustment programmes, and limited government are evident, the nation is on the brink of taking a very different development path. A reflexively modernised India will certainly not resemble a reflexively modern Europe as described by theorists such as Beck, Giddens and Lash (1994), Beck (1992; 1994; 1998), Giddens (1994), and Lash (1993; 1994; 1999). However, the signs are that India will become a $21^{\text {st }}$ Century, global economic, political, and cultural giant and therefore cannot be ignored. 


\section{Reflexive modernisation and globalisation}

The connection between reflexive modernisation and globalisation may be conceptualised with reference to the work of Held, et al. (1999). They trace the historical development of globalisation, dividing it into four phases: the pre-modern, early modern, modern, and contemporary stages. It is argued here that a fifth period of 'reflexive globalisation' has begun in which non-Western nations such as India and China are beginning to exert significant influence on the structures, institutions, and processes of globalisation (Table I). This 'reflexively modernising' globalisation is an intensification of the globalisation processes of the previous 'contemporary’ phase (Beck, 1994) and is characterised by transformations in the global economic, political, and environmental arenas. It is clear that globalisation is a major driving force in reflexive modernisation as it is 'changing the foundations of living together in all spheres of social action' (Beck 1998, p.17), however, the nature of globalisation has changed as a consequence of reflexive modernisation.

Insert Table I here

The significance of the transitions outlined in Table I to the case of India lies in the last two phases. Until the contemporary phase, India did not engage independently in a world trading system dominated by European colonial powers. However, since independence in 1946, India has begun to create opportunities and assert itself in the global political, economic, and cultural arenas. The emergence of India as an influential worldwide player has been since 2000 with the beginning of 'reflexive globalisation'. Contemporary globalisation has often been cast in terms of the creation of a 'world economy' (Braudel, 1984) or a 'capitalist world system' (Wallerstein, 1974) characterised by an inevitable and positive global triumph of capitalism and Western liberalism. As Beck (2000) explains, such globalisation privileges an 
institutionalisation of the Western capitalist model of a world market that excludes the prospect of frameworks and perspectives that have a non-Western origin or stance. The emergence of nations such as India differentiates reflexive globalisation as a broader process that requires possibilities of new interpretations in which it is possible and often desirable to place controls and limits on the capitalist 'market economy' and the trajectories of globalisation. In contrast to contemporary globalisation, reflexive globalisation has multiple points of departure and pathways.

Perhaps the most significant difference between reflexive globalisation and contemporary globalisation is conceptualised by the emergence of 'risk'. Beck (1998) refers to the concept of 'risk' arguing that the economic (industrial) development of modernity produces risks to the environment which in turn create social risks (eg expropriation of land, health hazards). These risks result in the questioning of the basis of modernisation resulting in an unseen and unintentional transition from modern industrial society to a reflexive risk society (Beck, 1992). According to Beck (1994), there are two periods: first, is the transition from traditional to modern industrial society and second is the transformation of industrial social forms into a reflexive modernity. This may be an accurate description of the European experience, however, in the context of non-Western societies such as India, the transition to industrial modernity and the subsequent transformation to reflexive modernity are happening simultaneously. This is significant because it changes the material nature of the processes at work and the consequences for society.

Risks are most evident in the spectre of global ecological threats and the emergence of global terrorist networks that are together creating a 'world risk society' in which such threats dominate public, political, and private debates and conflicts (Beck, 1992; 2002). On the one 
hand, society still makes decisions and takes action according to traditional perspectives but on the other hand, interest organisations, judicial systems, politics, and governments are clouded over by debates and conflicts that stem from the dynamism of risk society (Beck, 1994). India is no exception. One of the more compelling episodes is the ongoing debate in India about its response to terrorism focused recently by the August 2003 attack in Mumbai. Such risks and challenges to India as a nation state are, however, much broader and deeper than those arising from the environment and terrorism - these are just two of a range of globalising influences and trends. As Held and McGrew (2002, p.7) state, 'as economic, social and political activities increasingly transcend regions and national frontiers, a direct challenge is mounted to the territorial principle which underpins the modern state'. Globalisation is disrupting these activities of individual nation states and reconfiguring them within a new global dynamic. It is here that the reflexive modernisation thesis becomes useful in helping to gain understandings of this global dynamic and its effects not just on India but also on nations around the world.

As will become clear in the next section, just as India is undergoing a simultaneous transition to modernity and reflexive modernity, it also displays characteristics of both contemporary globalisation and reflexive globalisation. In India’s major cities, Delhi (10 million people), Mumbai (14 million people) and Calcutta (10 million people), contemporary globalisation is evident in the wide availability of Western-style consumer goods, rapidly rising real estate prices and transport infrastructure development that challenge traditional Indian religious and cultural practices. This is occurring alongside reflexive globalisation evidenced in risk producing severe pollution, undeveloped public health facilities for the masses (eg sewerage, water supply, hospitals), and widespread areas of slum housing, all of which pose significant threats to the well-being of the nation. In India, globalisation has brought compounded 
advantages for the privileged whilst reinforcing the vulnerabilities and disadvantages of being poor. It seems that India's simultaneous experience of contemporary globalisation and reflexive globalisation is presenting the nation with a number of challenges to its social, economic, and political development.

\section{The reflexive modernisation of India}

The unpredictable, far-reaching, and deep changes occurring to the social, economic, cultural, and political fabric of India as a result of globalisation has brought significant benefits. Conversely, it has also brought about social, economic, political, cultural, and environmental self-endangerment through the production of risks. The problem for India, as with other nations, is that the key economic, political, technological, and cultural flows and networks are often outside the abilities of its political systems to regulate and control. In the context of India, the usefulness of reflexive modernisation lies in the way it enables the surfacing of ambiguity, contradiction, and paradox arising from this situation and in doing so can be used to create alternative perspectives and policy approaches to development.

\section{Ambiguity}

Reflexive modernisation refers to there being a moment of loss of control leading to a state of chronic contingency (Lash, 1999). It is a state in which the past loses its ability to shape the present. Instead the future, something non-existent, unknown or fictitious takes its place as the cause of experience and action (Beck, 2000). This state is one of ambiguity, of wavering opinion, hesitation, doubt, and uncertainty as to one's course. India is in such a reflexively modern condition. On the one hand, it is on the cusp of taking a path towards rapid industrialisation and economic growth following the Western model of industrial capitalism, 
but on the other there is much doubt, uncertainty, and political debate about whether this path is the one India should be taking.

After World War Two, India rapidly decolonised. The leading political figures of the time set India on a path which they hoped would return it to cultural authenticity and self-assured identity. Bhagwati (2004) argues that rather than bringing benefits, this policy led the nation to adopting inward looking trade and investment strategies in the 1960s and 1970s that emphasised economic self-sufficiency in terms of industrial production. Bhagwati (2004) maintains that this caused sluggish economic growth with exports and income growing without enhancing living standards. Indeed, Nayar (2003) points out that this rush to industrial self-sufficiency was so beyond the capacity of the state that it led to a neglect and subsequent decline of key non-industrial sectors such as agriculture. This resulted in dependence on foreign food aid and foreign intervention in economic decision making culminating in the IMF imposing a structural adjustment programme in 1991. Rigby (1997) traces the effects of this programme. It opened the Indian economy to foreign capital flows and allowed seepage of sovereignty as multinational corporations moved in and tariff barriers came down. Whilst this opening-up of the Indian economy through the 1980s and 1990s has included liberalisation of the economy and a focus on exports, the government maintained controls on currency flows in and out of the nation. This spared India from the Asian financial crisis of the late 1990s (Stiglitz, 2002). This stands in contrast to other nations such as Thailand which fully embraced IMF policies of financial and capital liberalisation. According to Stiglitz (2002), Thailand was unable to withstand the effects of the downturn and experienced a major economic crisis which helped bring down neighbouring countries in South East Asia. 
Despite the departure of the colonial British rulers and the recent experience of IMF policies, parts of India still cling to Western notions and ideas of development reasoning that this is the way to becoming a prosperous and technologically advanced nation. There is doubt and uncertainty about which pathway to take into the future. Sardar (1997) argues the Indian mind must be decolonised and an authentic Indian future be built on the knowledge, experience, and categories of thought derived from Indian civilisation. The alternative is to follow the route taken by the 'Asian Tiger' economies and engage fully with the global economic, cultural, and technological system to follow the Western capitalist model of economic development.

This is the moment of ambiguity that India is now facing. The question arises as to whether the Indian policy responses will allow the nation to be swept along by the currents of Western-style globalisation leading the nation to modernise in an out of control way. The alternative is to find a development path that reflects Indian interpretations of modernisation and globalisation creating a hybrid model of development that contests the Western vision.

\section{Contradiction}

India's experience of both contemporary and reflexive globalisation has created a three-way socio-cultural contradiction between traditional ways of life, contemporary Western economic development ('modernisation') and the reflexive modernisation of society. Beck (1994) contends that reflexive modernisation includes a disembedding of culture and society from the taken-for-granted heteronomous social structures (family roles, class, race, gender, etc.) that formerly defined people's lives as these structures are dismantled and replaced by heterodoxical contingencies. According to Beck (1994) after disembedding there follows a process of re-embedding into new forms of life as new means of social integration and control 
are created. However, Baumann (2002) points out that there can be no re-embedding as the structures and institutions of a reflexively modern society are in a constant state of flux, so any re-embedding that takes place will only be transient. In Indian society, this disembedding/re-embedding is evident in the many contradictions arsing from attempts to graft Western-style structures and technologies onto traditional ways of life and the undermining of this development through the creation of risks.

Indian society displays a broad ethno-cultural diversity. It is a nation heavily burdened and conditioned by the past but is at the same time becoming more entangled in a present that is disconnected from tradition. According to the Indian Government, the future of India should be built on a rediscovery of the past, with focus towards the Indian attitude of destiny, action, non-alignment, and a spiritual attachment to nature (Kapoor 2004). Given this attitude, it may be argued that India, within a broader context, is not committed to the Western consumerist value system and would stand a better chance of creating a new and sustainable human order for the future (Kapur, 1982). Researchers such as Kapoor (2004) and Kapur (1982) argue that in spite of its innate spiritual and cultural beliefs, Indian society is fast becoming disembedded from traditional ways of life and adopting a materialistic, individualistic, and consumerist orientation. There is a deep contradiction emerging between the traditional Indian spiritual-compassionate disposition and the contemporary trend towards development, liberalisation, and globalisation.

This contradiction is evident in Channa's (2004) analysis. Channa (2004) argues that the opening up of India to the full impact of globalisation since the 1980s has led to the detraditionalisation of the nation. Channa maintains that the biggest mistake of the modern Indian state has been to try and graft a modern economy onto the traditional socio-cultural 
foundations without considering the implications of this. The traditional India is gradually being lost but there is no constructive alternative to replace it other than the Western model of modernisation through the introduction of modern technology. This has led to increasing poverty, a widening gap between rich and poor, and a confused and misdirected moral order. As long as the view is to sweep away unwanted traditions and ignore social evils such as malnutrition, health issues, and environmental destruction there is little hope of realising development goals of social justice and sustainability.

Pro-liberalists, such as Bhagwati (2004), argue that for the poor of India to raise their living standards, India must develop rapidly and increase economic growth. They contend that this can be achieved through the deployment and development of advanced technology to modernise the industrial base of the nation. Unless and until India fully accepts the argument that technological advancement can help alleviate poverty, the nation will be unable to develop into an advanced industrialised nation of global stature.

In contrast, Shiva (2004) argues against the rapid rate of technological development in India. She contends that such development creates a further and deeper divide between the elites and the masses through the creation of social, economic, and ecological risks. Pattnayak (2004) provides an example of this in an analysis of the push for technological advancement in West Bengal where the state government adopted and subsequently abandoned a policy encouraging small farmers to lease their land to multinational corporations in an attempt to modernise agricultural production, increase farm income, and improve productivity. Pattnayak (2004) points out that the policy had the reverse effect in that small farmers lost their right to cultivate the land resulting in increased unemployment and poverty. 
The example of farmers in West Bengal illustrates the contradictions created by globalisation and development in India as a whole. The social development of India combined with an increasing engagement with the global economy and international cultural and political institutions might be expected to cause a disembedding and disintegration of the traditional social divisions of the caste system allowing the poorer sections of society improve their living standards. Instead, these divisions are being reinvented taking the form of a separation of well educated, Westernised, globally connected, consumerist elite and wealthy middle class people from the non-Westernised, labouring, poor masses. The challenge is to reconcile the contradiction of a modern culture built on the principle of bahishkaar (ostracisation and exclusion) with principles that reinforce inclusion. The existence of a caste system and the social exclusion of poor people in India stand in stark contrast to the 'progressive we-havethe-bomb-and-are-no-longer-Third-World face’ (Thekaekara and van der Gaag, 2005, p.10) that India likes to present to the world.

The growth and development of India is following a path to reflexive modernity that is neither distinctly Western nor Indian. The development (modernisation) of the Indian economy, society, and culture is creating a process of disembedding from tradition but this is opening up fissures in the social, cultural, and economic fabric resulting from the risks created by industrialisation and technological change. This process is leading to the calling into question of a Western-style development path. Contradiction is evident in a time of contingency and uncertainty about a future that is making itself in ways that are unexpected with accompanying unforeseen economic, social, cultural, and political side effects. The challenge for India is to reconcile these contradictions in ways that create opportunities for finding alternative ways to prosperity and security. 


\section{Paradox}

The theoretical perspectives provided by reflexive modernisation allow a surfacing of the paradoxes arising from the relationship between economic development and the environment. It is paradoxical that nations such as India, in their drive towards modernisation, development, and enhanced social well-being are at the same time compromising that development through the production of environmental risks. The intention of modernisation is to create a society modelled on Western industrial capitalism. In spite of this, what is emerging, silently and unintentionally, is a reflexive society that must find ways of counteracting the risks of industrialisation through setting a course that runs across and against the grain of Westernstyle global capitalism (Beck 1992).

The paradox of economic development is illustrated in the first instance by examining the risks associated with such a course of action. Pachauri (2004) argues that the current rapid rate of development in India is unsustainable estimating a cost to the environment at $10 \%$ of India's GDP per year. This comes in the form of environmental degradation such as soil erosion, poor drinking water quality, deforestation, and air pollution. There is also a social dimension to this problem as these costs are being disproportionately borne by the poor. The main reason for this is that, as Shiva (2004) maintains, globalisation in the form of trade liberalisation is leading to a rapid modernisation of Indian agriculture through the application of technology such as genetically modified organisms, argo-chemicals, and mechanised production methods. Rather than leading to increased production and wealth in the rural sector and a more secure food supply for the nation it is instead leading to an erosion of biodiversity, and the privatisation and concentration of ownership of water and land resources. This not only threatens the food supply and livelihoods of the poor, it also threatens living standards of the more wealthy sections of Indian society. 
The paradox of India's economic development path can also be illustrated by following it to its logical (and some would argue impossible) conclusion. The push by the Indian government to advance technologically and become an industrial giant similar to Europe and the United States of America, if successful would reduce the rest of the world to an outer zone of markets (colonies) serving an Indian economic superpower. Pattnayak (2004, p.6) argues that significant economic development is dependent on the creation of colonies stating that, 'nations without colonies can attain a relatively affluent status only if great imperialist powers (the real giants) grant them concessions and access to equal rights of trade.' To illustrate this point, Pattnayak (2004) cites the example of European imperialism in which the major powers of Europe (eg Britain and France) exploited Africa and Asia whilst granting smaller European nations without colonies such as Switzerland and those of Scandinavia trade concessions which allowed them to develop. Pattnayak (2004) also points out that in the absence of colonisable regions overseas, a nation could choose to create 'internal colonies' to exploit. Resource rich communities could be marginalised and their produce used to enrich particular 'core' regions of a nation. In the case of India, this would add to the social and economic malaise in regional areas.

The ambiguity, contradiction and paradox of the development of India is characterised by the wealth gains flowing from such a trajectory being undermined by the production of a range of economic, social, and environmental risks. In particular, these risks have arisen from the exploitation of natural resources, environmental pollution, the industrialisation of agriculture, the concentration of land ownership, and the further impoverishment of society's most vulnerable people whilst the rich continue to increase their wealth. The theory of reflexive modernisation is clear about the consequences of this. Beck (1994) argues that there will be a gradual dissolution of society. For the most part the decline will go un-noticed by policy- 
makers and elites of society. Perhaps it will be only be detected when there is significant political, social, cultural, and economic deterioration - by which time the damage may be irreparable. The shape of a reflexively modern India has yet to be delimited, and polices developed that will help shape this development to minimise its negative consequences. Given the rapid growth of the Indian economy, this task is urgent and globally important.

\section{Conclusion}

This paper has demonstrated that there are multiple pathways to reflexive modernity and a number of routes to engaging with globalisation processes. India represents one such case. This challenges the argument that there is a single free-market capitalist model of globalisation and modernisation that all nations should follow. Using India as an illustrative case shows that there are no mutually exclusive categories of developed/developing nations or traditional/modern societies. Indeed these labels can be seen as being more ideological than indisputable features of the social, economic, and political landscape. India includes characteristics of both ends of each dichotomy and a range of combinations in between. This raises possibilities of creating new trajectories into the future. Further research is likely to include an emphasis on delimiting the wide variety of 'routes to and through [reflexive] modernity' (Beck et al, 2003, p. 7). Now is a good time to reconsider what a 'developing nation' is, to examine whether 'development' is an accurate concept, and to begin mapping the global contours of reflexive modernity.

Reflexive modernisation and the conceptualisation of five phases of globalisation provided a useful and powerful tool for analysing the current development policy trajectory adopted by India. It is argued here that not only is India modernising, we are also watching the reflexive modernisation of the nation. India is opening to the tide of Western-style globalisation 
through structural adjustment programs and trade liberalisation. There is no doubt that this brings tangible economic and social benefits. However, the idea of reflexive modernisation has illuminated the short-term nature of these benefits and their uneven distribution. It has also demonstrated how such development produces significant risks that have the potential to compromise the stability and sustainability of the nation. If India allows itself to be swept along by capitalist globalisation, it will eventually face the prospect of either developing at the expense of other nations or at the expense of its own people. The alternative is to find new ways of achieving long-term prosperity and security. Either way there is ambiguity, contradiction, and paradox. Organisations such as the World Bank and IMF guide developing countries such as India along the path of technological advancement and industrialisation and powerful capitalist countries endeavour to build these nations in their image creating a market for their own products and services. The challenge for India is to be neither colonial nor imperialistic but to seek self-identity with a new outlook towards development.

The vastness and diversity of India makes it difficult to generalise and speak about the nation as a whole. It can be concluded though that rapid economic growth and development based on free-market capitalism and the Western model of globalisation is not necessarily the most appropriate path towards sustainable development (Indiresan, 2004). Whilst rapid growth proved fruitful for some nations, others were less successful. Whilst Japan rose from the ashes of war to become a global economic, social, and cultural powerhouse, Argentina, after achieving relative post-war prosperity, imploded under the weight of foreign debt and IMF imposed structural adjustment programmes. The planned economy alternative is also no way forward. The Soviet Union rose to prominence in the first half of the $20^{\text {th }}$ Century but then disintegrated within a decade in the late 1980s and 1990s. This suggests such blueprints for development and globalisation do not provide answers, particularly if they are based on 
unsustainable policies and practices. However, if it is recognised that globalisation is an inevitable but ultimately controllable phenomenon then there may be a way forward. Means can be found to create the space for globalisation and improve national competitiveness whilst at the same time maximising national wealth to ensure improvements in living standards throughout Indian society (eg housing, health services, and education) in a sustainable way. The challenge for Indian political, social, and business leaders is how to confront the risks generated by development. They will need to face up to the need to ensure that economic growth resulting from globalisation does not compromise the social and cultural integrity of the nation. 


\section{References}

Baumann, Z. (2002), 'Individually, together', in U. Beck \& E. Beck-Gernsheim (Eds.), Individualization: institutionalised individualism and its social and political consequences, Sage Publications, London, pp.xiv-xix.

Beck, U. (1992), Risk society: towards a new modernity, Sage Publications, London.

Beck, U. (1994), 'The reinvention of politics: towards a theory of reflexive modernization', in U. Beck, A. Giddens \& S. Lash (Eds.), Reflexive modernization: politics, tradition and aesthetics in the modern social order, Polity Press, Cambridge, pp.1-55.

Beck, U. (1998), Democracy without enemies, Polity Press, Cambridge.

Beck, U. (2000), What is Globalisation?, Polity Press, Cambridge.

Beck, U. (2002), 'The terrorist threat: world risk society revisited', Theory, Culture and Society, Vol 19, No 4, pp.39-55.

Beck, U., Bonss, W., \& Lau, C. (2003), The theory of reflexive modernization: problematic, hypotheses and research programme, Theory, Culture and Society, Vol 20, No 2, pp.133.

Beck, U., Giddens, A., \& Lash, S. (Eds.) (1994), Reflexive modernization: politics, tradition and aesthetics in the modern social order, Polity Press, Cambridge. 
Bhagwati, J. (2004), In defense of globalization, Oxford University Press, New York.

Braudel, F. (1984), The perspective of the world, New York, Harper and Row.

Census of India (2001), Provisional population totals, New Delhi, Office of the Registrar General, retrieved 2 Dec, 2005 from http://www.censusindia.net/results/resultsmain.html.

Channa, S. M. (2004), 'Globalization and modernity in India: a gendered critique', Urban Anthropology, Vol 33, No 1, pp.37-71.

Clark, I. (1998), 'Beyond the great divide: globalization and the theory of international relations', Review of International Studies, Vol. 24, pp.479-498.

Dannreuhter, C., \& Lekhi, R. (2000), 'Globalization and the political economy of risk', Review of International Political Economy, Vol 7, No 4, pp.574-594.

Elliott, A. (2002), 'Beck's sociology of risk: a critical assessment'. Sociology, Vol 36, No.2, pp.293-315.

Giddens, A. (1994), 'Living in a post-traditional society', in U. Beck, A. Giddens \& S. Lash (Eds.), Reflexive modernization: politics and tradition in the modern social order, Polity Press, Cambridge, pp.56-109.

Held, D., \& McGrew, A. (2002), Globalization/Anti-Globalization, Polity Press, Cambridge. 
Held, D., McGrew, A. G., Goldblatt, D., \& Perraton, J. (1999), Global transformations: politics, economics and culture, Polity Press, Cambridge.

Indiresan, P. V. (2004), 'A 20-20 vision for India: targets, policies and implementation', Futures, Vol 36, No 6-7, pp.679-693.

Kapoor, R. (2004), 'Plural dreams: India in the 21st Century', Futures, Vol 36, No 6-7, p.637.

Kapur, J. C. (1982), India: an uncommitted society, New Delhi, Vikas Publishing House.

Lash, S. (1993), 'Reflexive modernization: the aesthetic dimension', Theory, Culture and Society, Vol 10, No 1, pp.1-23.

Lash, S. (1994), 'Reflexivity and its doubles', in U. Beck, A. Giddens \& S. Lash (Eds.), Reflexive modernization: politics and tradition in the modern social order, Polity Press, Cambridge, pp.110-173.

Lash, S. (1999), Another modernity, a different rationality, Blackwell Publishers, Oxford.

Nayar, B. R. (2003), 'Globalisation and India's national autonomy', Commonwealth and Comparative Policies, Vol 41, No 2, pp.1-34.

Pachauri, R. K. (2004), 'The future of India's economic growth: the natural resource and energy dimension', Futures, Vol 36, No 6-7, pp.703-713. 
Pattnayak, K. (2004), 'Vision of development: the inevitable need for alternatives', Futures, Vol 36, No 6-7, pp.671-679.

Rigby, A. (1997), 'Gram Swaraj versus Globalization', Peace and Change, Vol 22, No 4, pp.381-413.

Sardar, Z. (1997), 'Coming home: sex, lies and all the 'I's' in India', Futures, Vol 29, No 10, pp.891-908.

Shiva, V. (2004), 'The future of food: countering globalisation and recolonisation of Indian agriculture', Futures, Vol 36, No 6-7, pp.715-732.

Stiglitz, J. (2002), Globalization and its discontents, Allen Lane The Penguin Press, London.

Thekaekara, M. M., \& van der Gaag, N. (2005), 'Combatting caste', The New Internationalist, No. 380 (July), pp.9-12.

Wallerstein, I. (1974), The modern world system, New York, Academic Press. 


\begin{tabular}{|c|c|c|c|c|c|}
\hline & $\begin{array}{c}\text { Premodern } \\
\text { Pre-1500 }\end{array}$ & $\begin{array}{c}\text { Early modern } \\
1500-1760\end{array}$ & $\begin{array}{c}\text { Modern } \\
1760-1945\end{array}$ & $\begin{array}{c}\text { Contemporary } \\
1945-2000 \\
\end{array}$ & $\begin{array}{c}\text { Reflexive } \\
\text { 2000-present }\end{array}$ \\
\hline $\begin{array}{l}\text { Key global flows } \\
\text { and networks }\end{array}$ & $\begin{array}{l}\text { Early imperial } \\
\text { system } \\
\text { Long distance trade }\end{array}$ & $\begin{array}{l}\text { Political and military } \\
\text { expansion } \\
\text { Development of } \\
\text { European global } \\
\text { empires }\end{array}$ & $\begin{array}{l}\text { European global } \\
\text { empires, military, } \\
\text { political and cultural } \\
\text { flows - geopolitics } \\
\text { World economy }\end{array}$ & $\begin{array}{l}\text { Cold war and post } \\
\text { cold war global } \\
\text { military relationships } \\
\text { Multinational } \\
\text { production } \\
\text { Global ecological } \\
\text { threats. } \\
\text { Global media. }\end{array}$ & $\begin{array}{l}\text { Emergence of global } \\
\text { terrorist networks } \\
\text { (eg Al Qaida) } \\
\text { Global/local } \\
\text { production } \\
\text { Realisation of global } \\
\text { ecological threats (eg } \\
\text { global warming). } \\
\text { Convergence of } \\
\text { global media and } \\
\text { communication } \\
\text { networks }\end{array}$ \\
\hline $\begin{array}{l}\text { States borders and } \\
\text { territories }\end{array}$ & $\begin{array}{l}\text { All borders are } \\
\text { indeterminate }\end{array}$ & $\begin{array}{l}\text { Kingdoms and } \\
\text { empires }\end{array}$ & $\begin{array}{l}\text { Nation states } \\
\text { develop }\end{array}$ & $\begin{array}{l}\text { Nation state the } \\
\text { dominant political } \\
\text { unit } \\
\text { Emerging regional } \\
\text { units }\end{array}$ & $\begin{array}{l}\text { Challenges to nation } \\
\text { states } \\
\text { Emerging failed } \\
\text { states } \\
\text { Expansion of } \\
\text { regional units }\end{array}$ \\
\hline Modes & $\begin{array}{l}\text { Coercive } \\
\text { Religious/ideological }\end{array}$ & $\begin{array}{l}\text { Coercive } \\
\text { Imperial } \\
\text { Religious/ideological }\end{array}$ & $\begin{array}{l}\text { Coercive } \\
\text { Ideological } \\
\text { (increasingly } \\
\text { secular) } \\
\text { Competitive }\end{array}$ & $\begin{array}{l}\text { Competitive } \\
\text { Cooperative } \\
\text { Ideological/cultural }\end{array}$ & $\begin{array}{l}\text { Competitive } \\
\text { Networks } \\
\text { Ideological/cultural/ } \\
\text { religious }\end{array}$ \\
\hline
\end{tabular}

Table I. Globalisation in brief historical perspective (After Held et al, 1999). 